Summer 2007

\title{
Consumer Protection and Social Methods of Continental and Anglo-American Contract Law and the Transnational Outlook
}

Andreas Maurer

Osgoode Hall Law School

Follow this and additional works at: https://www.repository.law.indiana.edu/ijgls

Part of the Contracts Commons, Government Contracts Commons, and the International Law

Commons

\section{Recommended Citation}

Maurer, Andreas (2007) "Consumer Protection and Social Methods of Continental and Anglo-American Contract Law and the Transnational Outlook," Indiana Journal of Global Legal Studies: Vol. 14 : Iss. 2 , Article 8.

Available at: https://www.repository.law.indiana.edu/ijgls/vol14/iss2/8

This Symposium is brought to you for free and open access by the Law School Journals at Digital Repository @ Maurer Law. It has been accepted for inclusion in Indiana Journal of Global Legal Studies by an authorized editor of Digital Repository @ Maurer Law. For more information, please contact rvaughan@indiana.edu.

\section{$\Psi$}

JEROME HALL LAW LIBRARY

INDIANA UNIVERSITY

Maurer School of Law
Bloomington 


\title{
Consumer Protection and Social Models of Continental and Anglo-American Contract Law and the Transnational Outlook
}

\author{
Andreas Maurer ${ }^{*}$
}

\begin{abstract}
Debates over the content of recent EU directives and U.S. statutory amendments related to consumer protection highlight the importance of such regulation. Criticism calling for a return to freedom of contract in both regions reflects a tension between social ideals related to equality between private parties, and a deep distrust of state intervention and market regulation. With the rise of private sources for transnational commercial standards and practices, there is an opportunity for states to facilitate selfregulation in lieu of producing public substantive regulations. This approach seems to satify a well-established need for consumer protection without exacerbating government intervention in private contracts.
\end{abstract}

\section{INTRODUCTION}

Consumer protection in sales law has recently been subject to scrutiny on both sides of the Atlantic. In the European Union, debates on consumer protection have been triggered by the enactment of several consumer protection directives, especially directive 1999/44/EC ${ }^{1}$ on certain aspects of the sale of consumer

"The author is a German Lawyer (Rechtsanwalt) and LL.M. candidate at Osgoode Hall Law School of York University, Toronto, fellow at the Nathanson Centre for Transnational Human Rights, Crime \& Security and research assistant at Osgoode Hall Law School. It is gratefully acknowledged that the work on this article was funded by the Jack and Mae Nathanson Centre on Transnational Human Rights, Crime and Security and by Osgoode Hall Law School, York University, Toronto, Canada. E-mail: a_mau@web.de. I wish to thank the participants of the CLPE conference in Toronto in November 2006 for helpful remarks and stimulating discussions. I am especially indebted to Karl-Heinz Ladeur, Ralf Michaels, Luke Nottage, Chaim Saiman, David V. Snyder and Peer Zumbansen. Remaining mistakes are all mine.

1. Parliament and Council Directive 99/44, 1999 O.J. (L 171) 12 (EC). 
goods and associated guarantees, while in the United States, controversy has surrounded the revision of the Uniform Commercial Code's Article 2. For several reasons, it is interesting to take a closer look at those new regulations. One reason for closer scrutiny of those new regulations is the interest in comparative legal scholarship. But the most important reason is the significance of sales law within a legal and economic system. Karl Llewellyn called Article 2 of the UCC "the heart of the Code" and directive 1999/44/EC has been said to touch "the essential fields of national state private law like no other legislative activity before." ${ }^{3} \mathrm{Gar}$ diner C. Means noted that since all persons are consumers, the public interest embraces the consumer interest and therefore calls for consumer protection. ${ }^{4}$ Furthermore, President Kennedy stated that "consumers by definition include us all." Because of this importance of sales law, any changes should be closely followed and scrutinized, especially if they are accompanied by such severe debates as the innovations previously mentioned.

Consumer protection in sales law is discussed on two levels. On the first level, the subject of the debate is the scope and appropriateness of consumer protection provisions and their place within a given regulatory framework. This approach is a rather doctrinal one describing concrete measures of consumer protection like information duties, the scope and content of consumer warranties, and, accordingly, consumer remedies in the case of noncompliance with specific rules and regulations. It explains the means by which consumer protection law tries to empower consumers and the extent to which courts may exercise jurisdiction over consumer contracts. ${ }^{6}$

Another approach to discussing consumer protection is a more institutional

2. Karl N. Llewellyn, Why We Need the Uniform Commercial Code, 10 U. FLA. L. Rev. 367, 378 (1957).

3. Hannes Rösler, Europäische Integration durch Verbraucherschutz: Entwicklungsursachen und Beschränkungen, Veraraucher und Recht 2003, available at http://www.vur-online.de/beitrag/37. html (translated by author).

4. Gardiner C. Means, The Consumer and the New Deal, in 173 The Annals of the American Academy of Political and Social Science 7, 14 (Thorsten Sellin \& Donald Young eds., 1934).

5. President's Message to Congress Strengthening of Programs for Protection of Consumer Interests, 87th Cong., 108 Cong. Rec. 4167 (Mar. 15, 1962) (statement of John F. Kennedy, President of the United States).

6. See, e.g., Daniel Keating, Sales-A Systems Approach (3rd ed. 2006), especially chapters 2 and 4; Iain Ramsay, Consumer LAW CASEBOoK, chapter 4, electronic resource available at http:// osgoode.yorku.ca/QuickPlace/iainramsay/Main.nsf/\$defaultview/ 83FBC6557DDA674A8525706B006D93E8/\$File/chapter4.doc?OpenElement (last visited Feb 19 2007); William R. Kutner, Consumer Product Warranties Under The Magunson-Moss Warranty Act And The Uniform Commercial Code, 62 Cornell L. Rev. 738 (1977). 
one. From this perspective consumer protection is a matter of regulation between market and state. Within this framework one will not only find discourses about consumer protection but also debates about contract law and its regulation in general. The question generally concerns to what extent the state should intervene in economic processes or to what extent the concept of freedom of contract should be subject to a hands-off approach, as in a laissez faire market. ${ }^{7}$

However, the distinction between the free market on the one side and the intervening state on the other is questionable from a legal realist perspective. Such a perspective would deny this distinction and unveil the fact that all markets are constituted and shaped by states. ${ }^{8}$ Against this background, questions of regulation between state and market would shift towards questions of cultural and social preferences in the constitution of society and the shape, task, and scope of contract law as one of the major tools of societal organization.

Aside from the problems we have to face with questions of consumer law regulation within the boundaries of nation states, cross-border trade poses new and urgent questions. Internet trade has made cross-border trade possible not only for major corporations but also for small businesses and consumers. Ebay traders sell products from their living rooms to remote buyers not only in different countries but sometimes on different continents. Small companies are now able to offer their products and services to consumers all over the world. The internet has opened markets for literally everybody in a manner inconceivable only fifteen years ago. However, issues of consumer protection remain the same in this context.

With this development, consumer protection no longer is a policy issue only of nation states but becomes an issue on an international level. Problems arising from that constellation are manifold. One question in this context would be whether we need consumer protection in those cross-border markets. If this question can be answered in the positive, the next question would be how consumer protection can be conceptualized and reached in a globalized marketplace. Can consumer protection

7. For this approach, see, e.g., Iain Ramsay, Consumer Law and the Search for Empowerment, 19 CaN. Bus. L. J. 397 (1991) (pleading to consider social and cultural questions into debates on consumerism); Iain Ramsay, Framework for Regulation of the Consumer Marketplace, 8 J. Consumer PoL'y 353 (1985) (sketching a framework for government intervention in the marketplace to protect consumers' economic interests); Geraint Howells and Thomas Wilhelmsson, EC AND US APproaches to Consumer Protection-Should the Gap be Bridged? 17 Y.B. Eur. L. 207 (1997) (identifying different consumer protection strategies in the United States and EU).

8. For a retrospective view on the legal realism movement, see Joseph William Singer, Legal Realism Now, 76 CaL. L. Rev. 465 (1988). On page 532 Singer, criticizing the law and economic movement, states: "It hides the extent to which public power is involved in running and operating a market." 
be achieved in a space where there are no states to enforce or even enact consumer protection provisions? What can consumer protection measures look like on a global level? Is the future of consumer protection in a worldwide marketplace a regulatory competition ${ }^{9}$ among major participants in the global marketplace, with either a race to the top or to the bottom, or can we find common core rules ${ }^{10}$ that will apply for a large number of traders all over the world?

In order to assess today's consumer protection standards on national levels I will first compare consumer protection standards in sales law in the United States and the EU. The United States and the EU are well established market economies, each equipped with an elaborate set of consumer protection rules. However, regulatory approaches to consumer protection in sales law are notably different. In order to approach issues of the regulation of cross border trade it will turn out to be quite useful to compare those market economies and legal systems and their histories in the relevant field of consumer law. This will show that the histories of consumer protection in sales law have followed quite similar trajectories; yet, the regulatory result is notably different.

The developments of consumer protection in the EU and in the United States are based on a critique of formal concepts of contract law. Having their roots in a liberal concept of societal organization and contract law, social necessities urged judges and legislatures to abandon strictly formal concepts of contract law in favor of partial judicial review of contractual terms, which materialized in concepts like the doctrine of unconscionability, duress, usury laws, judicial control of standard form contracts, and the like.

Against this background it seems counterintuitive that today we see debates among well regarded contract scholars demanding to go back to formal concepts of contract law. I will briefly outline this debate and introduce some of the arguments before using social models to explain the differences in U.S. and EU consumer protection law, as well as the debate on returning to formal concepts of contract law. It will be shown that neither liberal/formal approaches nor welfarist approaches will be able to cope with consumer protection problems caused by the globalization of trade. I will very briefly outline some developments that might indicate the emer-

9. For an overview of theories and varieties of regulatory competition, see Simon Deakin, Legal Diversity and Regulatory Competition: Which Model for Europe?, 12 Eur. L. J. 440 (2006), 441-445.

10. See, e.g., Rudolf B. Schlesinger, The Past and Future of Comparative Law, 43 A м. J. СoмP. L. 477, 481 (1995); Rodolfo Sacco, Diversity and Uniformity in the Law, 49 Ам. J. Coмp. L. 171, 179 (2001); Mauro Bussani and Ugo Mattei, The Common Core Approach to European Private Law, 3 Colum. J. Eur. L. 339 (1997). 
gence of a regulatory field of consumer protection between state and market where standard-setting by semi-private actors as well as state regulation and market selfregulation shape a new concept of consumer protection law. In a final step I will plead that attempts to achieve global consumer protection standards should not stop at promoting free market self-regulation but should remember learning experiences from regulatory histories in order not to abandon struggles and societal narratives from the history of today's consumer protection standards and therefore not fall behind consumer protection standards that have already been reached.

\section{Consumer Protection in Europe and the United States}

To outline the consumer protection standards in the European Union and the United States I will concentrate on the most important aspects, namely implied warranties and consumer remedies in the case of seller's non-compliance with consumer warranties.

\section{A. The European Directive 1999/44/EC}

The European approach to consumer protection in sales law is slightly different from the one in the United States. In the European Union one has to differentiate between a guarantee and conformity with the contract. What would be called an express or implied warranty in the United States is subsumed under the notion of "conformity with the contract" in EU law. A guarantee is either a slight extension of legally provided consumer protection standards or a contract sui generis that grants consumer rights that exceed legal consumer protection standards and that are usually paid for. According to EU law there is neither any need for express warranty or implied warranties at all nor is there a need for a written warranty if a consumer wants to assert any rights under consumer protection provisions. The basic principle is that "[t]he seller must deliver goods to the consumer which are in conformity with the contract of sale." The sales contract can of course contain express or implied, written or unwritten terms, but they do not have to be referred to as warranties and it does not matter whether they are "full" or "limited" warranties. ${ }^{12}$

Pursuant to Article 2(2) of the directive, consumer goods are presumed to be in conformity with the contract if they (a) comply with the description given by

11. Parliament and Council Directive 99/44, art. 2, II 1, 1999 O.J. (L 171) 12 (EC).

12. Actually the terms "full" and "limited" warranty do not apply to EU law since the legal requirements for consumer rights cannot be altered by the seller. See id. at art. 7, II. 
the seller and possess the qualities of the goods which the seller has held out to the consumer as a sample or model; (b) are fit for any particular purpose for which the consumer requires them and which he made known to the seller at the time of conclusion of the contract and which the seller has accepted; and (c) are fit for the purposes for which goods of the same type are normally used. These provisions conform to what in the United States is known as an implied warranty for merchantability or fitness for a particular purpose.

Article 2(2)(d) of the directive provides a consumer protection standard that exceeds standards in the United States under the Uniform Commercial Code and the Magnuson-Moss Warranty Act. This provision allows for consumer actions if the seller of a consumer good does not comply with formerly made public statements such as advertisements, flyers and the like. ${ }^{13}$ It reads:

goods are presumed to be in conformity with the contract if they... (d) show the quality and performance which are normal in goods of the same type and which the consumer can reasonably expect, given the nature of the goods and taking into account any public statements on the specific characteristics of the goods made about them by the seller, the producer or his representative, particularly in advertising or on labelling. ${ }^{14}$

Article 2(5) of the directive, which provides that goods are deemed defective if they are incorrectly installed in the case that installment was part of the contract and even if the consumer installs the product incorrectly due to a shortcoming in the installation instructions, also exceeds U.S. consumer protection standards.

If consumer goods do not comply with those standards the consumer has the right to require the seller to repair or replace the goods. ${ }^{15}$ If the seller does not re-

13. In Skelton v. General Motors Corp., 660 F. $2 \mathrm{~d} 311$ (7th Cir. 1981), the court held that brochures, manuals, consumer advertising and other forms of communications circulated generally to the public are not "written warranties" as required by Congress in the Magnuson-Moss Warranty Act. However, in the revised version of UCC $\S 2-313 A$ and $\S 2-313 B$, similar provisions to the EU regulations have been created for remote purchasers. For a comprehensive explanation, see Linda J. Rusch, Is the Saga of the Uniform Commercial Code Article 2 Revisions Over? A Brief Look at What NCCUSL Finally Approved, 6 Del. L. Rev. 41, 64-68 (2003).

14. Parliament and Council Directive 99/44, art. 2, II 2, 1999 O.J. (L 171) 12 (EC).

15. Id. at art. $3, \mathbb{I} 2$. 
pair or replace within a reasonable time, the buyer may claim compensation, ${ }^{16}$ require appropriate reduction of the price, or rescind the contract. ${ }^{17}$

Another important feature of the directive is its statute of limitations. Consumer claims are limited to those defects that become apparent within two years after delivery. That feature does not apply to defects that develop after delivery. That means that a buyer can only claim rights under the directive if the product was defective upon delivery, even if the defect does not show up immediately but within two years from delivery. ${ }^{18}$ Under Article 5(3) of the directive any lack of conformity which becomes apparent within six months of delivery of the goods shall be presumed to have existed at the time of delivery, unless proved otherwise by the seller.

According to Article 7 of the directive the seller cannot waive any rights of the consumer unless seller and buyer agree upon a waiver after the buyer has noted a defect. A guarantee under the directive is an agreement that gives the consumer rights that exceed those rights established by the directive. ${ }^{19}$ This directive, intended to grant a minimum standard of consumer protection, had to be adopted by the Member States. However, Member States may impose regulations with higher consumer protection standards.

This directive was transformed into German law by the law on the modernization of the Law of Obligations in 2002. It is complemented by regulations on standard form contracts as well as regulations on distant selling transactions and doorstep sales. Those provisions together provide a fairly high standard of consumer protection in Germany and in the European Union.

\section{B. Consumer Protection in Sales Law in the United States}

Consumer protection in sales law is complex and non-uniform. ${ }^{20}$ Not only do many states have their own special consumer protection laws, but understanding consumer protection in sales law always requires viewing at least two acts together. On the state level, there is the Uniform Commercial Code (UCC), which provides for general regulations on consumer warranties, and on the federal level,

16. Id. at art. $3, \mathbb{I} 1$.

17. $I$ d. at art. $3, \llbracket \llbracket 2,5,6$.

18. Id. at art. 5 , Il 1 .

19. Id. at art. 6.

20. Kutner, supra note 6, at 767; Burt A. Leete, A Look at the Consumer Warranty Problem-The Federal Solution, 6 U. ToL. L. Rev. 351, 378 (1975). 
the Magnusson-Moss Warranty Act regulates consumer warranties by amending and complementing the UCC. ${ }^{21}$

\section{Warranties Under the UCC}

Consumer product warranties have always been governed by state law. ${ }^{22}$ The protections against the sale of goods of poor quality that are available to consumers in the United States exist primarily through the provisions of UCC Article 2 relative to express warranties, implied warranties of merchantability, and fitness for particular purpose. ${ }^{23}$ It is remarkable that the provisions on express and implied warranties in the UCC correspond precisely with the European regulations on consumer warranties. Express warranties in the United States are governed by UCC $§ 2-313$. This provision in its 2003 revised version reads:

(1) In this section, "immediate buyer" means a buyer that enters into a contract with the seller.

(2) Express warranties by the seller to the immediate buyer are created as follows:

(a) Any affirmation of fact or promise made by the seller which relates to the goods and becomes part of the basis of the bargain creates an express warranty that the goods shall conform to the affirmation or promise.

(b) Any description of the goods which is made part of the basis of the bargain creates an express warranty that the goods shall conform to the description.

(c) Any sample or model that is made part of the basis of the bargain creates an express warranty that the whole of the goods shall conform to the sample or model.

(3) It is not necessary to the creation of an express warranty that the seller use formal words such as "warrant" or "guarantee" or that the

21. In this work the main emphasis will be put on the UCC even if many states have adopted this uniform law with notable alterations. It is, however, impossible to scrutinize all different state laws within the limitations of an article like this.

22. Leete, supra note 20 , at 353.

23. Id.; Jennifer S. Martin, An Emerging Worldwide Standard for Protections of Consumers in the Sale of Goods: Did We Miss an Opportunity with Revised UCC Article 2?, 41 TEx. InT'L L.J. 223, 267 (2006). 
seller have a specific intention to make a warranty, but an affirmation merely of the value of the goods or a statement purporting to be merely the seller's opinion or commendation of the goods does not create a warranty.

(4) Any remedial promise made by the seller to the immediate buyer creates an obligation that the promise will be performed upon the happening of the specified event. ${ }^{24}$

This simply means that the goods have to be in conformity with the contract, similar to the result reached under Article 2(1) and (2)(a) of directive 1999/44/EC. An express warranty under UCC section 2-313 is the standard which the goods must meet as established by the bargain that the parties made for themselves. An express warranty can be created by a positive statement by the seller but also arises as to "[a]ny description of the goods which is made part of the "basis of the bargain' or by exhibition of a sample or model which is the "basis of the bargain."'s The question, then, becomes: when is something part of the basis of the contract? The code, however, does not answer this question. Although the term "basis of the bargain" is not defined in the code, the original comment eight to section 2313 notes that all the statements of the seller are part of the "basis of the bargain" unless good reason is shown to the contrary. ${ }^{26}$ This definition corresponds quite well with the requirement of directive 1999/44/EC that consumer goods must comply with the description given by the seller.

The implied warranty of fitness for a particular purpose as laid out in UCC section 2-315 corresponds almost exactly with directive 1999/44/EC Article 2(2)(b). UCC section 2-315 reads:

Where the seller at the time of contracting has reason to know any particular purpose for which the goods are required and that the buyer is relying on the seller's skill or judgment to select or furnish

24. For the provisions addressing express warranties in a non-privity context, see U.C.C. $\$ \S 2$ $313 \mathrm{~A}$ and 2-313B (2003). For a detailed explanation of these provisions, see Rusch, supra note 13.

25. Leete, supra note 20 , at 354 (quoting U.C.C. $\$ 2-313(1)$ (b)).

26. U.C.C. $\$ 2-313 \mathrm{cmt} .8$ (1997); see also Leete, supra note 20, at 354 (discussing how and when a statement becomes a part of the "basis of the bargain"); Richard A. Lord, Some Thoughts About Warranty Law: Express and Implied Warranties, 56 N.D. L. Rev. 509, 528-537 (1980) (explaining the concept of "basis of the bargain" for pre-sale and post-transaction settings). 
suitable goods, there is unless excluded or modified under the next section an implied warranty that the goods shall be fit for such purpose. $^{27}$

In both cases the buyer must need the purchased goods for a particular purpose, and the seller must know of that purpose at the time of the conclusion of the contract. UCC section 2-315 also requires that the buyer must rely on the seller's skill or judgment to select or furnish suitable goods. Those skills and judgments, however, are implied by the European directive. The effect of this warranty is to ensure that the purchased goods meet such standards as are necessary to fulfill the buyer's purposes. $^{28}$

The last warranty provided by the Uniform Commercial Code is the warranty of merchantability. UCC section 2-314, which deals with the implied warranty of merchantability, reads:

(1) Unless excluded or modified (Section 2-316), a warranty that the goods shall be merchantable is implied in a contract for their sale if the seller is a merchant with respect to goods of that kind. Under this section the serving for value of food or drink to be consumed either on the premises or elsewhere is a sale.

(2) Goods to be merchantable must be at least such as

(a) pass without objection in the trade under the contract description; and

(b) in the case of fungible goods, are of fair average quality within the description; and

(c) are fit for the ordinary purposes for which goods of that description are used; and

(d) run, within the variations permitted by the agreement, of even kind, quality and quantity within each unit and among all units involved; and

(e) are adequately contained, packaged, and labeled as the agreement may require; and

(f) conform to the promise or affirmations of fact made on the container or label if any.

27. U.C.C. $\$ 2-315$ (2003).

28. Leete, supra note 20, at 355; Lord, supra note 26, at 597-601. 
(3) Unless excluded or modified (Section 2-316) other implied warranties may arise from course of dealing or usage of trade. ${ }^{29}$

While the European directive 1999/44/EC only requires that consumer products "are fit for the purposes for which goods of the same type are normally used," 30 mirroring UCC section 2-314 (2)(c), the UCC focuses on several requirements for goods to meet, among them trade standards for merchantability, user standards of acceptability, safe packaging standards, and standards imposed by label statements.

Against this background it seems like the United States has at least an equal if not higher standard of consumer protection in sales law. Nevertheless, Martin's comprehensive article on comparative consumer protection law states that although the revision of UCC Article 2 has improved consumer protection in the area of quality of goods, the United States is "far removed from the highest standard that prevails at this time, that of the EU, as well as standards present in other countries." ${ }^{31}$ One explanation is that neither the express warranties nor the implied warranties provided in the UCC are mandatory provisions. Unlike directive 1999/44/EC, which in Article 7 states the binding nature of the rights under all circumstances, the UCC allows for contracting around express as well as implied warranties, ${ }^{32}$ although a disclaimer of express or implied warranties has to meet certain standards under the UCC. A warranty waiver must be on record, conspicuous, and state that the seller undertakes no responsibility for the quality of the goods except as otherwise provided in the contract. ${ }^{33}$ Also, warranties can be disclaimed if the seller uses expressions like "as is," "with all faults," "as they stand," and the like, ${ }^{34}$ or if the buyer examines the goods prior to entering the contract or refuses to examine the goods after a demand by the seller..$^{35}$ An implied warranty may also be excluded or modified by course of dealing, course of performance, or usage of trade. ${ }^{36}$ Finally, the seller's remedies can be limited according to UCC section 2-316(4). Even though the UCC offers consumers some help regarding quality of goods by providing regulations on express and implied warranties, Ar-

\footnotetext{
29. U.C.C. $\$ 2-314$ (2003).

30. Parliament and Council Directive 99/44, art. 2, If 2(c), 1999 O.J. (L 171) 12 (EC).

31. Martin, supra note 23, at 266.

32. U.C.C. $\$ 2-316(2)$ (2003).

33. Id.

34. Id. $\$ \S 2-316(3)(\mathrm{a}), 2-316 \mathrm{cmt} .5$.

35. Id. $\$ 2-316(3)(\mathrm{b})$.

36. Id. $\$ 2-316(3)(\mathrm{c})$.
} 
ticle 2 is "premised on the notions of freedom of contract and party autonomy." 37 The disclaimer section of the UCC enables merchants to shift "the risk of loss back to consumers while camouflaging their action with legal jargon. ${ }^{38}$ At the time when the Magnuson-Moss Warranty Act was enacted, the UCC seemed to be not very protective of consumers. Indeed, the only protective element was the UCC's articulation of the doctrine of unconscionability, which, however, was not a very useful device for buyers in actual litigation. ${ }^{39}$

Part of this void is filled by the Magnuson-Moss Warranty-Federal Trade Commission Improvement Act. ${ }^{40}$

\section{The Magnuson-Moss Warranty Federal Trade Commission Improvement Act}

The Magnuson-Moss Warranty Act (“Act”) was enacted on July 4, 1975 and is codified in United States Code Title 15, sections 2301 through 2312. The main provisions of the Act contain standards for written warranties that are considered "full warranties," ${ }^{\text {"41 }}$ set forth disclosure ${ }^{42}$ and designation ${ }^{43}$ requirements for written warranties, and provide for consumer remedies if the warranty is breached. ${ }^{44}$ If a full warranty is given, the warrantor is obliged "to correct defects, malfunctions, or nonconforming quality defects without charge and within a reasonable time, to disclose clearly on the face of the warranty the exclusions or limitations of consequential damages, and to permit refund or replacement after reasonable but unsuccessful attempts to repair. ${ }^{35}$ However, the Act does not compel the seller to provide for a "full warranty" which is one that meets all standards set forth in 15 U.S.C. $\$ 2304$. Yet, if a warranty does not meet the standards of a full warranty, the seller has to conspicuously designate it as a "limited warranty." ${ }^{\text {"46 }}$

37. Martin, supra note 23, at 266; accord U.C.C. \$ 1-102 cmt. 2 (2003) ("Subsection (3) states affirmatively at the outset that freedom of contract is a principle of the Code"); In Re S. Prop., Inc., 44 B.R. 838, 843 (Bankr. E.D. Va. 1984) ("The [Uniform Commercial Code] was drafted to facilitate commercial transactions and freedom of contract.").

38. Donald P. Rothschild, The Magnuson-Moss Warranty Act: Does it Balance Warrantor and Consumer Interests?, 44 Geo. Wash. L. Rev. 335, 344 (1976).

39. Curtis R. Reitz, Consumer Protection Under the Magnuson-Moss Warranty Act 14 (1978).

40. Alex Devience, Jr., Magnuson-Moss Act: Substitution for UCC Warranty Protection?, 95 Coм. L.J. 323, 337 (1990).

41. 15 U.S.C. $\$ 2303(\mathrm{a})(1)$ (2000); accord 15 U.S.C. $\$ 2304$ (2000).

42. Id. $\S 2302$.

43. Id. $\$ 2303$.

44. Id. $\$ 2310$; Leete, supra note 20 , at 361-62.

45. Rothschild, supra note 38 , at 355 (internal citations omitted).

46. 15 U.S.C. $\$ 2303$ (a)(2). 
The great advantage of the Act for consumers over UCC warranty provisions is that once a written warranty-full or limited-is made, the warrantor cannot disclaim express or implied warranties under the UCC except to limit them to the duration of the written warranty, if that limitation is reasonable, conscionable, and prominently displayed on the face of the warranty in clear, unmistakable language. ${ }^{47}$ A violation of the Act permits the Attorney General or the Federal Trade Commission (FTC) to sue warrantors under the Federal Trade Commission Act in the U.S. district courts in order to restrain deceptive warranties or noncompliance. ${ }^{48} \mathrm{~A}$ consumer damaged by a breach of warranty or noncompliance with the Act or FTC regulations promulgated thereunder may sue for injunctive relief, damages, or any other legal relief. ${ }^{49}$ Although there exists the possibility to file actions against noncomplying warrantors before state and federal courts, the legislature has made clear that informal dispute resolution mechanisms are preferred..$^{50}$ However, the Act does not cover oral warranties, and such warranties might be precluded from evidence by the parol evidence rule, under UCC \$ 2-202. ${ }^{51}$ Yet, the seller still may sell products "as is" or without written warranty to avoid the effects of the UCC warranty provisions and of the Act.

\section{Levels of Consumer Protection in the United States and European Union}

The sections on express and implied warranties in directive 1999/44/EC and in the UCC appear very similar at first glance. Both codifications require sellers to fulfill express warranties and help to establish reliable standards for quality of consumer goods with implied warranties of merchantability and fitness for a particular purpose. In those regulations the UCC and the directive only differ marginally. However, there are major differences in the warranties' binding effects as well as in their time limitations. European merchants can not contract so as to avoid implied warranties or to reduce the duration of consumer rights from two years after delivery. ${ }^{52}$ Additionally, for the first six months after delivery, merchants bear the burden of proof that the good was not defective at the time of de-

47. 15 U.S.C. $\$ 2308(a)-(b)(2000)$.

48. Id. $\S 2310(\mathrm{~b})-(\mathrm{c})$.

49. Id. $\$ 2310(\mathrm{~d})$.

50. Id. $\$ 2310$ (a); Rothschild, supra note 38 , at 368-77.

51. Keating, supra note 6 , at 213.

52. However, it is possible, in German law, for example, to reduce the time limit to one year if the sold good is used. Bürgerliches Gesetzbuch [BGB] [Civil Code] § 475 (2). 
livery. ${ }^{53}$ U.S. merchants may be bound by express and implied warranties as soon as they have given consumers a written warranty, but the UCC allows parties to contract around express and implied warranties and the Magnuson-Moss Act, even if it prohibits disclaiming given warranties, allows the sale of goods "as is." Effectively, it is possible to reduce the duration of a warranty or eliminate any warranties by the terms of a given agreement. The UCC as well as the Act leave gaps that allow merchants to shift the risks of consumer goods back to the consumer which EU law does not.

\section{Reasons for Differences in Consumer Protection Standards}

The histories of the EU and U.S. legal systems explain the differences in consumer protection standards. The U.S. legal system, as well as most Western European legal systems, has developed in the philosophical traditions of individual freedom and equality, which emphasize individual property rights and freedom of contract. Classical contract theory in the United States had its roots in the decades following the civil war and was based on the prevailing economic philosophies in America during the eighteenth and nineteenth century. ${ }^{54}$ Those were the heydays of laissez faire philosophy and therefore classical or traditional theory of contract law was understood to mean that individuals had inalienable rights to own property and therefore to make their own contracts, and that the state and thus the law should interfere with people as little as possible. ${ }^{55}$ Legal philosophy on both sides of the Atlantic was strongly influenced by the principles of individual freedom prominently promoted by Immanuel Kant. Political philosophy rested upon the proposition that "the end of man was freedom." Law system was taken to exist in order to secure individual interests against arbitrary invasion by the state or society. ${ }^{57}$ In sales law, this was reflected by the application of the doctrine of caveat emptor, which was the expression of the ideal of a

53. Parliament and Council Directive 99/44, art. 5, II 3, 1999 O.J. (L 171) 12 (EC).

54. Caroline Edwards, Article 2 of the Uniform Commercial Code and Consumer Protection: The Refusal to Experiment, 78 ST. JoHN's L. Rev. 663, 673 (2004); see also Morris R. Cohen, The Basis of Contract, 46 Harv. L. Rev. 553, 553-54 (1933).

55. P.S. Atiyah \& Stephen A. Smith, Atiyah's Introduction to the Law of Contract (6th ed. 2005).

56. Roscoe Pound, The End of Law as Developed in Juristic Thought II, 30 HARv. L. Rev. 201, 204 (1917).

57. Roscoe Pound, The End of Law as Developed in Juristic Thought I, 27 HARv. L. Rev. 605, 625 (1914). 
society where equal citizens could freely bargain over the contractual terms of a consumer product sale. The doctrine of "let the buyer beware" allocated the risk of the quality of a purchased product to the buyer. The concept of caveat emptor that corresponded with this political philosophy of individual freedom and equality and the economic concept of laissez faire was seen in 1870 to have been adopted by the common law in almost every state..$^{58}$ The autonomy of private parties to make their own contracts on their own terms was the central feature of classical contract law. ${ }^{59}$ The concept of freedom of contract and therefore the enforcement of private contracts was the main concern of common law courts and was believed to be in the public interest. Sir George Jessel wrote:

[I]f there is one thing which more than another public policy requires it is that men of full age and competent understanding shall have the utmost liberty of contracting, and that their contracts when entered into freely and voluntarily shall be held sacred and shall be enforced by Courts of justice. Therefore, you have this paramount public policy to consider- that you are not lightly to interfere with this freedom of contract. ${ }^{60}$

In Continental Europe the concept of freedom of contract was state of the art as well. The first drafts of the German Civil Code were made in the 1870 s, slightly less than 100 years after the French Revolution, which gave rise to the enactment of the famous code civil. Those codes again were inspired by the Enlightenment and based on the concept of freedom of contract. The ideas of free and equal individuals forming the state by contractual relations were the foundation of the new codifications. However, before the German Civil Code was enacted in 1900, scholars argued against an almost unlimited freedom of contract in the German Civil Code. One of the most famous among the critics was Otto von Gierke who coined the phrase "a little drop of social oil," new Civil Code, and argued for more rights for the poor in the new codification.

The age of the industrial revolution brought up problems that had been seen

58. Barnard v. Kellogg, 77 U.S. 383, 388-89 (1870) ("Of such universal acceptance is the doctrine of caveat emptor in this country, that the courts of all the States in the Union where the common law prevails, with one exception (South Carolina), sanction it.").

59. Patrick S. Atiyah, The Rise and Fall of Freedom of Contract 408 (2003).

60. Printing and Numerical Registering Co. v. Sampson, 19 L.R., Equity, 462, 465 (1875) (U.K.).

61. Otto v. Gierke, Die soziale Aufgabe des Privatrechts: Vortrag gehalten am 5. April 1889 in der JURistischen Gesellschaft zu Wien, 10. 
before by lawyers and judges. The ideal of a society of free and equal citizens turned out to be an illusion. Morris Cohen stated in 1933 that "[ $[$ ]he freedom to make a million dollars [was] not worth a cent to one who was out of work.' ${ }^{\prime 2}$ The ideal of freedom of contract means little to someone who lacks the means or talents to make contracts for food, clothing, shelter, or employment. It then appeared that the concept of freedom of contract was not necessarily a warranty for fair trade and just societies. ${ }^{63}$ Formal law seemed insufficient to cope with social realities. The ideal of free and equal citizens turned out to be nothing but a mere fiction of what was found in everyday life. Freedom that was formally guaranteed became worthless for those parts of society that lacked the material preconditions to use their personal liberties. Against this background, the rise of the so-called welfare state must be seen as an institutional reaction to social grievances. ${ }^{64}$

In Germany, between 1916 and 1922 several laws ${ }^{65}$ replacing and amending the very formal and non-comprehensive law of service contracts in the German Civil Code marked the first steps to a new labor law. Since 1948 at the latest, when the German Basic Law (Grundgesetz) came into force anchoring the concept of the welfare state in the German Constitution, ${ }^{66}$ the liberal individualistic model of the German Civil Code could no longer be retained. The insight that inequalities and disparities between highly professional market participants and uninformed and inexperienced consumers were realities of modern market societies led to the emergence of a completely new field of law-consumer protection law. Starting with the Standard Contract Terms Act in the 1970s, consumer protection soon became a dominant concept in German private law. However, the enactment of the Standard Contract Terms Act was preceded by more than 25 years of "open" judicial review of standard contract forms. In this context "open" control asopposed to a "covert" or "camouflaged" control-means that courts openly address the question of whether a term is acceptable in substance or not rather than pursuing "strict constructions" or holding that "surprise" clauses were not really

62. Cohen, supra note 54 , at 560 .

63. AтiYah \& SMith, supra note 55, at 11.

64. Id. at 14 .

65. The Hilfsdienstegesetz of 5th Dec. 1916, the Betriebsrätegesetz of 4th Feb. 1920 and the Gesetz über die Entsendung von Betriebsratsmitgliedern in den Aufsichtsrat of the 15th Feb. 1922. See Richardi et al., Betriebsverfassungsgesetz Mit Wahlordnung: Kommentar (2006), Recital 11.

66. Article $20 \mathrm{sec} .2$ of the German Grundgesetz (Basic Law) reads: "The Federal Republic of Germany is a democratic and social federal state." 
agreed. ${ }^{67}$ Based on the German Act on Standard Contract Forms, the EU has adopted the Council Directive 93/13/EEC of 5 April 1993 on unfair terms in consumer contracts. ${ }^{68}$ Today, due to European legislation, more than half a dozen consumer protection laws are integrated into the German Civil Code and harmonized with the member states of the European Union.

A similar picture appears to be drawn in Northern America. In the 1960s courts had to cope with the exploitation of poor and uneducated people. The solution for such problems chosen by U.S. courts was the application of the doctrine of unconscionability, codified in $\$ 2-302$ UCC but also recognized as a common law principle, ${ }^{69}$ in order to justify non-enforcement of substantially unfair contracts. The highly controversial landmark case on unconscionability in the United States was Williams v. Walker Thomas Furniture Company, in which the Court of Appeals for the District of Columbia declined to enforce an unfair contract for the reason of unconscionability. ${ }^{70}$ Walker Thomas offered credit to customers, many of whom were not regularly employed and would not be granted credit otherwise. The credit terms were exorbitant: interest rates were high, security was retained in all goods purchased, and goods were repossessed after even trivial defaults. ${ }^{71}$ Mrs. Williams was-known to Walker-Thomas-a welfare recipient with many children and Walker-Thomas sought to repossess all goods purchased after Mrs. Williams had already paid more than two-thirds of the complete purchase price and then defaulted. Justice Skelly Wright, writing for the court, held that Ms. Williams lacked bargaining power due to an obvious lack of education and therefore she had no real choice, making the contract unconscionable and therefore not enforceable. ${ }^{72}$ Although the doctrine of unconscionability was and still is highly disputed and was partly received with great suspicion, ${ }^{73}$ it has found

67. Konrad Zweigert and Hein Kötz, Introduction to Comparative Law 336 (1998).

68. 1993 O.J. (L95) 29.

69. Williams v. Walker-Thomas Furniture Company, 350 F.2d 445, 448-49 (D.C. Cir. 1965).

70. See generally id.

71. Id. at 447.

72. Id.

73. Arthur Leff, Unconscionability and the Crowd-Consumers and the Common Law Tradition, 31 U. Pitr. L. Rev., 349, 354 (1969) ("[H]e (Professor Murray) appears to believe that regulation of the quality of mass-distribution contracts requires some open-textured directive to courts to strike naughty provisions, and that the proper governmental quality agency is an unguided court. I don't."); Arthur Leff, Thomist Unconscionability, 4 CAN. Bus. L. J. 424 (1979) (pointing out the difficulties in defining the term "unconscionable"); Recent Case, Williams v. Walker Thomas Furniture Co., 350 F.2d 445 (D.C. Cir. 1965), 79 Harv. L. Rev. 1299, 1301 (1969) (Fearing that the awareness of the doctrine would encourage breaches by individuals who had signed particularly bad bargains, with the hope they would successfully defend themselves by portraying their bad deals as an 
its way into the legal system. Today, as Douglas Grant predicted in $1969,{ }^{74}$ the doctrine of unconscionability is well established and, although previously codified in the UCC sales law section, is applied by analogy to all kinds of contracts. ${ }^{75}$

In the Williams v. Walker-Thomas line of cases and in German case law that led to consumer protection legislation, societal needs which had not been a central topic of law before came into the sight of judges and legislatures. Social realities were no longer ignored against a background of idealistic concepts like freedom of contract, or, in other words, judges like Skelly Wright are important actors in a symbolic representation of the conflict between individualism and altruism in the search for an altruist social order. ${ }^{76}$ Williams $v$. Walker Thomas can be seen as a milestone social development that recognized the existence of inequalities among formally free and equal citizens. Against this background, the introduction of the doctrine of unconscionability was a legal reaction to urgent social problems that had emerged. An unchallenged application of the doctrine of freedom of contract "enabled skilled and powerful sellers to perpetrate injustices upon unsuspecting consumers burdened with goods which failed to meet their reasonable expectations." ${ }^{\text {7 }}$

The awareness that strong sellers can be a danger to weaker parties (not only consumers) has arisen in the United States ${ }^{78}$ as well as in Europe. ${ }^{79}$ But the reactions are different. While U.S. legislation tended to favor the concept of freedom of contract, especially in the UCC, ${ }^{80}$ the European Union has on many occasions

unconscionable contract.); Eben Colby, What did the Doctrine of Unconscionability Do to the WalkerThomas Furniture Company?, 34 ConN. L. Rev. 625 (2002) (pointing to the fact that the application of the doctrine of unconscionability in the Williams case had little effect on the day-to-day operations of Walker-Thomas. Several other factors like poor customers' general inherent fear of the legal system or a lack of representation had the effect that in some areas like Harlem ninety-seven percent of recovery suits never went to trial (citing J.Skelly Wright, The Courts Have Failed the Poor, N. Y. Times, Mar. 9, 1969, § 6 (Magazine), at 26).

74. Douglas L. Grant, Current Decisions, Williams v. Walker Thomas Furniture Company, 350 F. $2 d$ 445, 38 U. Colo. L. Rev. 289, 291 (1969).

75. Restatement (Second) of Contracts $\$ 208$ (1981).

76. Duncan Kennedy, Form and Substance in Private Law Adjudication, 89 Harv. L. Rev. 1685, 1777 (1976).

77. Edwards, supra note 54, at 667.

78. E.g., id. at 663 .

79. E.g., Peter Ulmer, Hans Erich Brandner \& Horst-Diether Hensen, Agb-Gesetz: Kommentar zum Gesetz zur Regelung des Rechts der Allgemeinen Geschäftsbedingungen 30 (1977) (citing the EU parliament hansard 7/3919).

80. U.C.C. \& 1-102 cmt 2 (2003) ("Subsection (3) states affirmatively at the outset that freedom of contract is a principle of the Code: 'the effect' of its provisions may be varied by 'agreement."'); Edwards, supra note 54, at 667; Kutner, supra note 20, at 739. 
enacted consumer protection provisions that harshly interfere with a formal concept of freedom of contract. Consumer protection and its realization in the member states has become such an important policy that it has even been incorporated as a main target of EU policy in the EU treaties. ${ }^{81}$

Even though consumer protection approaches, and approaches to contract law in general, ${ }^{82}$ are as different in the United States and the European Union as has been described above, criticisms of state interventions and alleged encroachments in the freedom of contract by state legislation are surprisingly unanimous on both sides of the Atlantic. Very recently, many scholars have demanded a return to the formal concept of freedom of contract, criticizing legislative state intervention as well as juridical interventions. Behind those critiques lies a deep suspicion of state intervention and a profound hope that the market's invisible hand is able to create better welfare for all citizens than state intervention ever will.

\section{Contract Law and Consumer Protection Between State and Market}

The concept of freedom of contract, and the question of how much freedom is ideal, inundates discussions on contract law today. This question leads into the heart of contract law as it points to a crucial distinction between contracts and agreements that are enforced and those that are not. The problem is drawing a line between those two kinds of agreements. In North America as well as in Europe, and especially in Germany, legal scholars have argued recently for a very strict conception of contractual freedom, which means that the state should limit itself to the enforcement of contracts exactly as the parties have agreed upon. Schwartz and Scott, for instance, conclude their comprehensive legal and economic analysis with the appeal that courts should not create default rules for contracting parties with the statement that "firms want the state to enforce the contracts that they write, not the contracts that a decisionmaker with a concern

81. Consolidated Version of the Treaty Establishing the European Community (EC) 16 Apr. 2003, art. 153, 2006 O.J. (C 231) 115-16:

1. In order to promote the interests of consumers and to ensure a high level of consumer protection, the Community shall contribute to protecting the health, safety and economic interests of consumers, as well as to promoting their right to information, education and to organise themselves in order to safeguard their interests.

82. See U.C.C. $\$ 1-102 \mathrm{cmt} .2$. 
for fairness would prefer them to have written." ${ }^{83}$ Their major claim is that contract law should do nothing more than "facilitate the efforts of contracting parties to maximize the joint gains. ${ }^{\text {} \$ 4}$ Kull advocates leaving parties alone in cases of frustrated contracts or mistake. He argues that "[d]isparities between anticipation and realization in contractual exchange, ... are in the nature of 'windfalls'... The law will not act to enforce such windfalls — to compel an exchange on terms that were not bargained for-because its objective is limited to giving effect to the parties' agreement." ${ }^{\text {"ss }}$ Scott claims that formalist modes of interpretation of contracts offer the best prospect for maximizing the value of contractual relationships, ${ }^{86}$ and Bernstein points out the difficulties of discovering unwritten codes of conduct that are applied by courts. ${ }^{87}$

In Germany, several renowned legal scholars recently have criticized European developments in consumer protection law as endangering the concept of freedom of contract. Michael Martinek has noted a "hypertrophy of consumer protection law"88 and demands for a "résistance of the formal ethics of freedom" to prevent a development of "deprivation of liberty." He argues for a "re-privatization" of private law, meaning less state regulation of contract law in fields including labor law, consumer law, and landlord and tenant law, and pleads for more freedom of contract. ${ }^{89}$ Canaris has even doubted the compatibility of European consumer protection law with the German Constitution, arguing that consumer protection that limits private autonomy is unsocial and illiberal. ${ }^{90}$ Although the diversity of problems that are covered by authors arguing for a formal concept of freedom of contract and the variety of arguments being accounted for makes it impossible to categorize them comprehensively, I will call the adherents of a con-

83. Alan Schwartz \& Robert E. Scott, Contract Theory and the Limits of Contract Law, 113 YALE L.J. 541,618 (2003).

84. Id. at 544 .

85. Andrew Kull, Mistake, Frustration, and the Windfall Principle of Contract Remedies, 43 HAsTINGs L.J. 1, 6 (1991).

86. Robert E. Scott, The Case for Formalism in Relational Contract, 94 Nw. U. L. Rev. 847, 875 (2000).

87. See Lisa Bernstein, The Questionable Empirical Basis of Article 2's Incorporation Strategy: A Preliminary Study, 66 U. CHI. L. Rev. 710, 712-17 (1999).

88. Michael Martinek, Vertragsrechtstheorie und Bürgerliches Gesetzbuch (Dec. 17-19, 2005), available at http://www.jura.uni-sb.de/projekte/Bibliothek2/text.php?id =375 (translated by author). 89. Id.

90. Claus-Wilhelm Canaris, Wandlungen des Schuldvertragsrechts-Tendenzen zu seiner "Materialisierung," 200 ArChiv für die civilistische Praxis 273, 362-364 (2000). 
tractual theory that favors little state intervention-and therefore a formal concept of contract law-formalists.

On the other side of the debate we will find authors that I will call welfarists. Lawyers in common law countries as well as in civil law countries have been arguing for a more social concept of private law. Zweigert and Kötz, for instance, ask whether the concept of freedom of contract can still be maintained or if it has to be replaced by a concept of justice of contract against the background of bargaining inequalities and the necessity for protection of weaker parties. ${ }^{91}$ Blumberg concludes that the common law of contracts is insufficient to cope with market failures and therefore demands strict legislative intervention, ${ }^{92}$ and Howells and Wilhelmsson, analyzing the latest biases in European consumer law, plead for a reassessment of substantive policies rather than having faith in information and market forces. ${ }^{93}$

Such categorizations are certainly crude and do not justify the distinct concepts behind them. In fact, it is doubtful whether consumer protection is a program of the welfare state at all since the welfare state focused on health, housing, education, and social security. ${ }^{94}$ In this context, a formal approach shall be understood as a hands-off approach to economic processes where the state's task shall be to enforce contracts as the parties have agreed upon and a welfarist approach shall be understood as one that promotes state intervention into economic processes if that seems to be in some conception of the public interest.

\section{Social Models in Contract Law}

This analysis raises several questions. Is it possible to go back to a nineteenth century conception of formal private autonomy? Are formalists that demand a return to private autonomy wrong? Is it really desirable to promote a hands-off approach and cut back state intervention into contract law? These questions can certainly be answered in the negative. One point to argue against a hands-off ap-

91. Konrad Zweigert \& Hein Kötz, An Introduction to Comparative Law 331 (3rd ed. 1998).

92. Phillip I. Blumberg, Consumer Protection in the United States: Control of Unfair or Unconscionable Practices, 34 Ам. J. Сомp. L. 99, 123 (Supp. 1986).

93. Garaint Howells and Thomas Wilhelmsson, EC Consumer Law: Has it Come of Age?, 28 Eur. L. Rev. 370, 388 (2003).

94. Iain Ramsay, Consumer Law and the Search for Empowerment, 19 CAN. Bus. L.J. 397, 401 (1991). 
proach has already been made by realist writers like Hale. ${ }^{95}$ The market "is not a natural pre-political institution and ... the particular form of 'private' market relations reflects a political compromise backed up by state force." 96 The notion of state intervention into a pre-existing set of free relations therefore becomes less convincing. Another argument is that the developments toward consumer protection standards that we have today, as outlined above, cannot be ignored. Those developments reacted to externalities-side effects of free exchange. ${ }^{97}$ One of those externalities is the development of strong professional sellers that are highly skilled and experienced and therefore are able to build up a much stronger bargaining position than the average consumer. Such developments cannot be reversed. Externalities are firmly entrenched in society, as are regulatory laws that are supposed to ease negative effects arising from such externalities. ${ }^{98} \mathrm{~A}$ formalist approach that demands a return to formal concepts of freedom of contract simply ignores the historical and social developments that have led to the necessity of state intervention into allegedly free markets. For those reasons a return to nineteenth century formal concepts of contract law and freedom of contract are impossible from today's perspective.

But why are scholars still promoting a "return to private autonomy?" And why are there others who think that state regulation does not go far enough? To understand this debate one will have to take a different perspective. The debate about market self-regulation and state intervention has to be seen as a debate over different social models in our societies.

One way to understand social models is a socio-economic concept. National policies have developed different ways of coping with markets and market failures. Specific ways of handling market failures end up in different ways of organizing the state and of imposing limits to markets that again mark different levels of social welfare. Regulation therefore is "embedded" in socially acceptable forms of economic behavior and governance..$^{99}$ In that context, so called "liberal market econo-

95. See generally Robert L. Hale, Bargaining, Duress, and Economic Liberty, 43 Colum. L. Rev. 603,628 (1943) (arguing that "by judicious legal limitation on the bargaining power of the economically and legally stronger, it is conceivable that the economically weak would acquire greater freedom of contract"); Robert L. Hale, Coercion and Distribution in a Supposedly Non-Coercive State, 38 Pol. Sci. Q. 470, 470 (1923) (arguing that there is "a need for the development of economic and legal theory" to protect the freedom to contract).

96. Ramsay, supra note 94, at 404 (summarizing Hale's arguments).

97. AтіYah \& Smith, supra note 55, at 11.

98. Id. at 20.

99. See generally Peter A. Hall \& David Soskice, Introduction to Varieties of Capitalism: The Institutional Foundations of Comparative Advantage 1-68 (Peter A. Hall \& David Soskice 
mies" like that of the United States are based on "standard market relationships and enforceable formal contracts," 100 whereas so called "coordinated market economies" like Germany and other members of the European Union such as Denmark, Belgium, the Netherlands, Austria, Sweden, Norway, Finland, France, and Italy ${ }^{101}$ encourage relational contracting. ${ }^{102}$ Those different kinds of political economies correspond with different types of welfare states. ${ }^{103} \mathrm{~A}$ social model in this sense can be seen in a closed system of market-correcting socio-economic regulation. ${ }^{104}$ Distinct socio-economic environments certainly played a role in the development of consumer protection standards in the European Union and the United States.

But another perspective shall also be included in this analysis. The notions of "social models," "social ideas" or "social visions" have also become generally accepted in order to describe the images and narratives of society inscribed in a legal system. ${ }^{105}$ The notion being used in this sense is not new. As early as 1931, Otto Kahn Freund examined the social model of the German Supreme Labor Court (Reichsarbeitsgericht) during the Weimar period, criticizing that the Supreme Labor Court realized a fascist social ideal. ${ }^{106}$ Almost two decades later in 1952 Franz Wieacker delivered his famous lecture in which he elaborated the paradigm of bourgeois formal law and clarified the background against which the "materialization" of law during the last one hundred years could emerge. ${ }^{107}$ This social transformation of law was initially thought of as a process in which a new instrumental understanding of law, one related to social-welfare conceptions of justice, was superimposed on the liberal model of law, which it suppressed and finally supplanted. ${ }^{108}$

Today the notion of social models is an integral part of European policy. In 2000 the Nice European Council meeting approved the European Social Agenda ${ }^{109}$ and stated:

eds., 2001) (discussing the intricacies of various economic systems).

100. Id. at 30 .

101. Id. at 20, tbl. 1.1 .

102. See id. at 26.

103. Id. at 50 .

104. Thomas Blanke \& Jürgen Hoffmann, Auf dem Weg zu einem Europäischen Sozialmodell: Voraussetzungen, Schwierigkeiten und Perspektiven einer europäischen Sozialpolitik, 39 KRIrIsche Justiz 2, 134-50 (2006).

105. Jürgen Habermas, Paradigms of Law, 17 CArdozo L. Rev. 771, 771 (1996).

106. Otto Kahn-Freund, Das soziale Ideal des Reichsarbeitsgericht, Thilo Ramm (ed.), Arbeitsrecht und Politik-Quellentexte 149, 205 (1918-1933).

107. Franz Wieacker, Das Sozialmodell der klassischen Privatrechtsgesetzbücher und die Entwicklung der modernen Gesellscha ft (1953).

108. Habermas, supra note 105 , at 771 .

109. 2001 O.J. (C157) 4. 
To prepare for the future, the Union must rely on its achievements. It must continue to promote its inherent values of solidarity and justice as enshrined in the Charter of Fundamental Rights. The European social model characterised in particular by systems that offer a high level of social protection, by the importance of the social dialogue and by services of general interest covering activities vital for social cohesion, is today based, beyond the diversity of the Member States' social systems, on a common core of values. ${ }^{110}$

Two years later the European Council described the social model as follows:

The European social model is based on good economic performance, a high level of social protection and education and social dialogue. An active welfare state should encourage people to work, as employment is the best guarantee against social exclusion. The European Council considers the Social Agenda agreed at Nice to be an important vehicle for reinforcing the European social model. ${ }^{111}$

These official statements show "that the term 'European social model' is to encompass more than a mere model of social policy." 12 The documents rather make reference to embracing characteristics in the dimensions of state, economy and society. ${ }^{113}$ Implicitly and explicitly the term is often used in European official documents to distinguish a European type of society from the type of society in the United States, sometimes with a rather competitive edge. ${ }^{114}$

Against this background the notion of social models shall also be understood as the social and economic ideas of individuals, groups of a society, or entire societies. A social model shall be understood as the collection of hopes, expectations, and prospective anticipations of a society. Conceived in this way a social model incorporates all hopes and expectancies that are set forth in the state as the entity that is able to regulate social and economic developments. Different social models then reflect different images of what the state is capable of doing and what it should do.

110. Id. at $5 \S 11$.

111. Presidency Conclusions, Barcelona European Council 8 \$22 (Mar. 15-16, 2002).

112. Jens Alber, The European Social Model and the USA, 7 Eur. Union Pols. 393 (2006), 394.

113. Id.

114. Id. 
Those images, however, are different in the United States and in the EU. While Europeans consider the state rather as something potentially "good" which exists to create better living conditions for the citizens, American societal thinking conceives the state rather as something bad against which civil liberties have become a necessary shield. ${ }^{115}$ This is not surprising since many of the first American colonists fled from oppression of European States based on religion or other reasons. ${ }^{116}$

In this context, Howells and Wilhelmsson refer to Albert Hirschmann's wellknown analysis of exit, voice and loyalty ${ }^{117}$ and describe how "exit" has always been an integral part of U.S. culture. ${ }^{118}$ Hirschmann himself states quite clearly that " $[w]$ ith the country having been founded on exit and having thrived on it, the belief in exit as a fundamental and beneficial social mechanism has been unquestioning." 119

In contrast, we can see European welfare states where the conception of liberal civil rights as rights against the states has been complemented by a conception that understands civil rights also as social rights. That of course strongly influences the political agenda. Refering to the German "Sozialstaatsklausel,"120 Howells and Wilhelmsson state: "The citizens expect the state to protect them from evil and assist them if evil occurs."121

Howells and Wilhelmsson recognize those differences especially in the consumer field:

The consumer field appears as one where such a difference between American and European attitudes can be noted. Whilst collective consumer activism has been a prominent feature of American consumer markets, Naderism being the catchword in this context, European consumer protection has in many countries been developed from above, by the State. ${ }^{122}$

115. Howells \& Wilhelmsson, supra note 7, at 210.

116. Id.

117. Albert Hirschmann, Exit, voice, and loyalty: Responses to Decline in Firms, OrganiZations, and States (1970).

118. Howells \& Wilhelmsson, supra note 7 , at 210.

119. Hirschmann, supra note 117 at 112.

120. Grundegesetz für die Bundesrepublik Deutschland [GG] [Basic Law] May 23, 1949, art. 20, $\S 2$ reads: "The Federal Republic of Germany is a democratic and social federal state." (translated by author).

121. Howells \& Wilhelmsson, supra note 7, at 210 .

122. Howells \& Wilhelmsson, supra note 7, at 212 . 
Admittedly, the picture that Europeans love their state as a redeemer and Americans would rather live their lives without the state is a very crude categorization. However, it shows a certain bias and helps us understand why expectations of European and U.S. consumers are likely to be different and why therefore EU and U.S. consumers show different behaviors. It also helps to understand different approaches to regulation on both sides of the Atlantic. Those social models not only describe societal differences between the EU and the United States, they also reflect certain biases in legal scholarship.

Against this background, the debate among scholars on whether state regulation or freedom of contract should prevail in consumer protection law appears in a completely new light. The demand for a return to more formal concepts of contract then appears as a deep suspicion against state intervention and severe mistrust in the state's capability to regulate markets.

Such distrust is often founded in experiences with the welfare state dating from the 1980s, 1990s, and today. The welfare state as it is known today faces severe structural problems. In 1981, Niklas Luhmann identified the crisis of the welfare state, most notably its economic viability. ${ }^{123}$ Indeed, today Germany and other European countries that have established comprehensive welfare states struggle with the costs of their welfare and social security systems. But the crucial problems of the welfare state go deeper. If the materialization of private law, as consumer protection measures and other infringements of private autonomy are often called, is conceived as state regulation of society, then the question arises whether and to what extent such regulation is possible at all. The systems theory approach denies the possibility of social regulation by the state, critiquing it for being a self-referential, autopoietic, closed system that cannot be effectively regulated. "The political system can ... only regulate itself." 24 Whether or not one may be convinced by the system theory approach, it cannot be denied that state regulation has reached several crucial points.

State regulation today is also challenged from a different direction. Transnational ${ }^{125}$ trade poses completely new challenges to national state regulation. The internet, with its almost unlimited opportunities for cross-border trade, enables

123. See generally Nikgas Luhmann, Politische Theorie im Wohlfahrtsstaat 25-32 (1981), translated in Niklas Luhmann, Political Theory in the Welfare State 25-29 (John Bednatz, Jr. trans., 1990) (discussing theoretical foundations of political theory).

124. Niklas Luhmann, Die Wirtschaft der Gesellschaft 324 (2002).

125. Gralf-Peter Calliess, Reflexive Transnational Law: The Privatisation of Civil Law and the Civilisation of Private Law, 23 Zeıtschrift für Rechtssozıologie 185, 185-86 (2002) (F.R.G.) (defining the term "transnational"). 
not only huge enterprises but also small and medium-sized businesses to sell merchandise all over the world. Professional sellers on the Ebay auction website are only one example for this emerging world-wide market place.

\section{Consumer Protection in a World-wide Market Place}

In a rapidly emerging transnational consumer market, concepts of strict state regulation become less convincing since cross-border trade makes state intervention largely impossible. ${ }^{126}$ Even though there may be conflicts norms regulating which jurisdiction applies to certain consumer businesses, the problem will increasingly be the factual impossibility of enforcement of consumer rights. Even if a European consumer had claims under U.S. consumer protection law, it would in most cases be economically senseless to pursue such claims, especially if the consumer claim is a matter of only a few dollars. Even claims of thousands of dollars might not be raised due to enormous enforcement costs. This shows that the need for consumer protection is increasing rather than decreasing in cross-border markets, but it cannot be achieved by state regulation.

In this context, one interesting fact should be mentioned: certain consumer protection standards are often provided by large sellers themselves instead of being imposed on them by states. Return policies and product warranties given by sellers often voluntarily provide higher standards of consumer protection than state regulation does. Amazon.com, for example, offers a 30-day return policy for a full refund of the purchase price. That applies to most products sold on Amazon.com with the exception of groceries, gift certificates, prepaid phone cards, and products with missing serial numbers. ${ }^{127}$ Amazon.de, the German subsidiary of Amazon.com, however, offers a 30-day money back guarantee only for books. ${ }^{128}$ For electronic products like camcorders and digital cameras as well as for small electronic appliances, the state law regulating distant sales contracts (i.e. contracts

126. See Gralf-Peter Calliess, Transnational Consumer Law: Co-Regulation of B2C-E-Commerce, in Responsible Business: Self-covernance in transnational economic transactions (Olaf Dilling , Martin Herberg \& Gerd Winder eds., forthcoming 2006), available at http://www.jura. uni-muenchen.de/einrichtungen/ls/calliess/publikationen/CalliessTransnationalConsumerLaw2006.pdf.

127. Amazon, General Returns Policy, http://www.amazon.com/gp/help/customer/display. html? nodeld $=15015711$ (last visited May 10, 2007).

128. Amazon, Details zur Rücksendung und Beispiele, wenn Sie das Produkt von Amazon.de gekauft haben, http:/www.amazon.de/gp/help/customer/display.html/303-6952611-5747432?ie $=$ UTF8 \& nodeId $=504972$ (last visited May 10, 2007). 
that are concluded over the internet or via telephone or fax) applies with only its 14-day cooling-off period. ${ }^{129}$ That is only one example of a lower degree of consumer protection standards through state regulation.

Admittedly, the 30 -day return policy addresses only a very narrow issue and European regulations offer a lot more consumer protection standards than only a prolonged cooling-off period, but this example shows that consumer protection standards can be achieved without state regulation. Those kinds of self-commitments might be seen as soft law or even less binding than that, but a closer look at the emergence of some consumer protection institutions on a social field between state and market shows that there are ways to stabilize such self-commitments to consumer protection standards. Institutions like the German Stiftung Warentest, the Technischer Ueberwachungsverein (TUEV), and the American Consumers Union not only monitor and supervise quality standards of products but also observe standard contract terms of market participants. In some cases, negative ratings have triggered reviews of standard contract terms by sellers. ${ }^{130}$ Such private or semi-private consumer ${ }^{131}$ protection organizations are backed up by state courts as long as their tests and ratings are neutral, clinical, and knowledgeable, ${ }^{132}$ the statements are not false, and the tester has not acted with actual malice. ${ }^{133}$ Such consumer protection organizations are not singular phenomena. The Trans Atlantic Consumer Dialogue ${ }^{134}$ combines sixty-five consumer protection organizations (profit, non-profit, public, quasi public, strictly private, mostly independent) in many different fields and different markets.

129. See Bürgerliches Gesetzbuch [BGB] [Civil Code] Jan. 2, 2002, Bundesgesetzblatt 42, § $312 d$ (F.R.G.).

130. For example, the German Organization of Car-Sharing Providers decided to review its standard contract terms at its nationwide meeting. Treffen, CS-FF, Carsharing-Fachorum, bundesweites Treffen der 'U21'-CSO auf Einladung des bcs, http://wiki.carsharing-fachforum.de/ cgi-bin/twiki/view/CSFF/Treffen (last visited May 10,2007). This change was due to bad ratings by the Stiftung Warentest. Press Release, Stiftung Warentest, Was Weiterbildungstests anbieterseitig bewirken (Jan. 20, 2006), available at http://www.stiftung-warentest.de/online/bildung soziales/weiterbildung/meldung/1334951/1334951/1334969.html.

131. The Stiftung Warentest is a private foundation that was established by the federal government. The Consumers Union of United States, Inc. is a non-profit New York corporation.

132. For ratings of the German Stiftung Warentest see BGH VI ZR 157/73, 09 Dec 1975, in 29 Neue Juristische Wochenschrift 1976, 620 (Haftung der Stiftung Warentest für vergleichende Tests - Liability of Stiftung Warentest for comparative product testing).

133. For an example illustrating the existence of the Consumer Union in the United States, see Suzuki Motor Corp. v. Consumers Union, 330 F.3d 1110 (9th Cir. 2003).

134. Trans Atlantic Consumer Dialogue Homepage, http://www.tacd.org (last visited May 10, 2007). 
The internationally acting International Standardization Organization (ISO) sets up quality standards and management development guidelines and monitors the compliance of companies with those standards and guidelines. Internet platforms like Epinions.com or Ratings.net offer spaces for consumers to share experiences with quality standards of products and manufacturers or experiences they have made with traders.

Those organizations and institutions do not regulate consumer markets but they help to monitor traders' and manufacturers' compliance with quality and consumer protection standards to which traders and manufacturers have committed themselves. Noncompliance results in negative ratings, which again have direct impacts on consumer satisfaction and consumer trust and therefore have immediate economic effects. Those economic effects, especially if they are severe, can be even more expensive and influential on company policies than state-imposed legal sanctions. Against this background private consumer protection or standardization organizations can not replace state regulation but play an important role as watchdogs, which, by various strategies such as "naming and shaming" or provoking consumer boycotts, can force firms to observe certain social standards. ${ }^{135}$

To make it absolutely clear, those emerging consumer organizations do not yet replace state regulation or state courts. Until now, the globalization of consumer markets weakens consumer empowerment since affordable and reliable equivalents to state courts are still missing. But monitoring of quality standards and standard form contracts on return policies and other consumer protection measures by private and semi-private institutions and organizations helps to stabilize certain standards in transnational trade. If those standards are enforced by informal dispute resolution mechanisms or private dispute resolution organizations, as Calliess describes, ${ }^{136}$ we could be witnessing the emergence of consumer protection as a mixed regulatory field of state regulation, market self-regulation, and regulation by actors between state and market. The emergence of such regulatory fields makes the law appear as only one concept of market regulation among others like social norms (rules of fair dealing, e.g., goodwill refunds), economic incentives for sellers (e.g., consumer satisfaction, competition about consumer friendly return policies), and social institutions providing consumer information.

135. Dieter Kerwer, Rules that many use: Standards and Global Regulation, 18 Governance: AN International Journal of Policy, Administration, and Institutions 611, 618 (2005).

136. See, e.g., Gralf-Peter Calliess, Online Dispute Resolution: Consumer Redress in a Global Market Place, 7 German L.J. 647 (2006) (discussing systems of regulation via online resolution); Calliess, supra note 126, at 22-27 (discussing the standards and implementation procedures of online dispute resolution). 
The challenge will then be to coordinate legal and non-legal consumer protection provisions without forfeiting standards that have already been reached.

For states that want to regulate consumer protection standards this means that they will have to cope with problems from different directions. From a procedural perspective, states will have to deal with the fact that nation-states, as regulators of consumer protection measures, are not replaced but accompanied and complemented by other semi-public and private actors on both domestic and transnational levels. On a more substantive level, the question arises how the law can accommodate this shift of perspectives.

If the law does not have either the ability to regulate in a transnational context or the monopoly of regulation on domestic and international levels any longer, how can and should the state then react to that fact? One answer could be that the state should shift its subject of regulation. In the sense of Teubner's reflexive law, ${ }^{137}$ the state could withdraw from traditional regulation toward a regulation and regulative support of actors that are capable of acting sufficiently on a transnational level. This could include the endorsement and supportive regulation of consumer protection institutions that act on a global level like those discussed above. In any case, state regulation as we know it today will have to be profoundly reconsidered against the background of the irreversible movement of globalization.

\section{Conclusion}

Against the background of transnationally emerging markets, national consumer protection law seems to be insufficient to cope with cases involving cross border trade. A potentially emerging and developing transnational consumer law still lacks a body of norms to regulate legal relationships between traders and consumers as well as an institutional framework of dispute resolution. First steps towards the organization of dispute resolution frameworks might have been taken, ${ }^{138}$ but they are not yet sufficiently established and accepted by consumers. Besides the problems of establishing dispute resolution mechanisms the creation of applicable rules and regulations will play a major role in globalized markets.

At this point it is time to come back to the questions that were posed at the be-

137. Gunther Teubner, Substantive and Reflexive Elements in Modern Law, 17 Law \& Soc'y Rev. 239, 242 (1983).

138. Calliess, Online Dispute Resolution supra note 136; Calliess, Transnational Consumer Law: Co-Regulation of B2C-E-Commerce, supra note 126. 
ginning of this analysis. Do we need consumer protection in a globalized market? This question can be answered with reference to the reflections on social models in consumer protection law above. National consumer protection standards are the result of decades of painful struggles over questions of morality, justice and fairness, and are always subject to revision and change. Consumer protection standards as we find them today and as they have been outlined above are the heritage of more than a century of legal and socio-economic development. The results of those developments, however, are arguably different in Europe and North America. Nevertheless, those narratives and cultural achievements must not be abandoned in favor of a neo-liberal, apolitical matter-of-fact globalization. Instead, "in order to be able to spell out ... political aspirations ... [we should] remember the background against which we politically have been learning, hoping, and aspiring, for better or for worse."139 Peer Zumbansen explicitly points out the normativity of those learning experiences summarized under the term "social models" above:

Both heritage and path-dependencies are not only a burden, but with respect to the historical and contemporary struggles for political and social rights we should be aware of the normative dimension of this particular experience. And we ought to ask how to realize this experience both in its historical dimension and in its fragile normative aspiration. ${ }^{140}$

Therefore: Yes, we need consumer protection in a globalized market because the social problems, the political challenges and the power relations of consumer markets against which the development of consumer protection standards on national levels must be seen still exist on the global scale and demand reconciliation even if nation states are less likely to fulfil this task.

But who, if not nation states, will be able to regulate consumer markets? The brief analyses of market-observing and standard-setting non-state organizations like consumer unions or standardization organizations has shown that there are actors on the global stage that are able to develop various strategies to set and enforce social standards in consumer markets. Internet platforms like Epinions.com allow consumers to develop countervailing powers against globally acting market

139. Peer Zumbansen, Quod Omnes Tangit: Globalization, Welfare Regimes and Entitlements, in The Welfare State, Globalization, and International LaW 135, 161 (Eyal Benvenisti et al. eds., 2004).

140. Id. at 160 . 
participants. After all, a company's loss after a successful consumer boycott might be much more coercive and influential on future behavior than state-imposed legal sanctions. The rise of global standard-setting organizations, however, raises other questions of accountability of standard setters and opportunities for participation, which cannot be addressed here. ${ }^{141}$

Against the background of different social models, cultural narratives and normative expectations it is unlikely that we will see the emergence of one single set of rules for consumer protection. In the model that has been outlined in this paper, where firms commit themselves to consumer protection standards' in return policies and standard contract forms for the sake of competitive advantages, and where the compliance with such standards is monitored by consumer unions and voluntary loose associations of consumers, it is not unlikely to expect competition over consumer protection standards as well as the competition we see over prices and product qualities today. This, however, requires consumer awareness. Consumer protection standards have to be made subject to purchase decisions. If this can be achieved we could see regulatory competition with a race-to-the-top of consumer protection standards.

In this picture regulatory tasks would be profoundly redistributed. Substantive regulations would be a result of "self-regulation" in the sense of self-commitment to self-prescribed consumer protection standards of globally acting sellers. Compliance with such regulations would be observed and monitored by non-state actors, but monitoring by state actors would also be conceivable. The state's task would then be to support monitoring and to enable consumers to access information about the "market of consumer protection standards." Finally, the state will still be a stage of reassurance and development of the creation of political consciousness and awareness. It will serve as the provider of the public sphere in which cultural narratives and social ideas can be developed and continued in order to preserve the social memory that contains the choices made in the past as well as the reasons particular choices were made.

141. For a discussion of such problems see Dieter Kerwer, Rules That Many Use: Standards and Global Regulation 620-627 (2005). 